\title{
Strategy for Developing High Order Thinking Skills in Basic Automotive Technology Subjects at Jetis 1 in SMK Mojokerto
}

\author{
Sunwinarti ${ }^{1}$, M Samani $^{2}$, Muhaji $^{3}$, S Muslim $^{4}$, K S Budi $^{5}$ \\ \{ sunwinarti881@gmail.com ${ }^{1}$, msamani@unesa.ac.id ${ }^{2}$, \\ muhaji61@unesa.ac.id ${ }^{3}$,supari.muslim@gmail.com ${ }^{4}$ karnobudi16070895001@mhs.unesa.ac.id ${ }^{5}$ \}
}

\begin{abstract}
Mechanical Engineering Education, Universitas Negeri Surabaya, Indonesia ${ }^{1,2,3}$ Electrical Engineering Education, Universitas Negeri Surabaya, Indonesia ${ }^{4,5}$
\end{abstract}

\begin{abstract}
The ability that is considered important for the success of study, work, and living in the information and technology era in the 21 st century is High Order Thinking Skills (HOTS). The purpose of this study is to produce learning device products for basic automotive technology subjects using learning models based on HOTS-based problems that are valid, practical, and effective. The type of research used is quasi-experimental research (quasi experiment) which begins with the development of learning devices. Research Results: (1) the average score of critical thinking skills for students learning using HOTS-based problembased learning (PBL) models $\left(\mathrm{x}^{-}=82.96\right)$ was significantly higher than students who studied using the direct learning model or direct instruction (DI) with an average score of $\mathrm{x}^{-}=71.40$; and (2) the average score of creative thinking ability for students who learn using HOTS-based problem-based learning (PBL) models $\left(\mathrm{x}^{-}=49.14\right)$ is significantly higher than students who learn using direct or direct learning models instruction (DI) with an average score of $\mathrm{x}^{-}=74.66$.
\end{abstract}

Keywords: Media trainer, student learning outcomes, level of creative thinking, and vocational school

\section{Introduction}

The ability that is considered important according to Widihastuti \& Suyata for the success of the study, work, and living in the information and technology era in the 21 st century is High Order Thinking Skills or called HOTS [1]. The same thing was also conveyed by Cotton [2] and Robinson [3] that to enter the workforce, prospective workers must have the readiness, ability, and skills required by the workforce, one of which is HOTS. Aside from being stock to enter the workforce, Chinedu, Kamin, \& Olabiyi stated that HOTS can also help students to develop more innovative, perspective, and imaginative insights [4].

This made the government make various efforts to reduce the problem. Efforts are made in accordance with Presidential Instruction No. 9 of 2016 concerning the revitalization of vocational secondary schools in order to improve the quality and competitiveness of Human Resources (HR) which contain programs such as (1) alignment of the vocational curriculum; (2) increasing access to vocational graduates certification; (3) increasing cooperation and access to internships for students, educators and education personnel in the industrial world; (4) 
link and match program; (5) developing teaching factory; and (6) providing guest teachers, even assistance with infrastructure facilities. Therefore, we should no doubt teach our students how to think creatively and become critical thinking students who can solve problems in the future or not hesitate to teach completely about HOTS since they were in school even from an early age in the family environment as a form of quality improvement and competitiveness of human resources. Because of the importance of HOTS, according to Samani, Ismayati, Cholik, \& Suparji who stated that critical and creative thinking is very important, but still weak in these two abilities [5].

However, the efforts made are still not in accordance with the current situation, as shown by one of the international studies on students' cognitive abilities, namely the TIMSS (Trends in Mathematics and Science Study) conducted by the IEA (International Association for the Evaluation of Educational Achievement ) found that in 2007 and 2011, more than 95\% of Indonesian students were only able to reach the middle level in the field of mathematics and in the field of science. Unlike students in Taiwan who in the field of mathematics (50\%) and IPA $(40 \%)$ are able to reach high levels. The field of mathematics and science in the world of vocational education is a normative subject that is very important in supporting the learning process of productive subjects. It was also conveyed based on the TIMSS results, that high order thinking skills (HOTS) of Indonesian students were still low. This happens because in the learning process at school, according to Nurlaela \& Euis Indonesian students are generally less stimulated to increase HOTS students [6]. In general, the ability of Indonesian students is very low in terms of (1) understanding complex information; (2) theory, analysis, and problem-solving, (3) use of tools; and (4) conduct an investigation.

This is supported by the observation of one of the schools, namely at SMK Negeri 1 Jetis, Mojokerto Regency through interviews with productive teachers of TKR and TSM skills competencies. In the middle of the odd semester of class $\mathrm{X}$, students began to show interest and began to be enthusiastic when productive learning.

\section{Method}

The type of research used is quasi-experimental research (quasi-experiment) which begins with the development of learning devices. In subject research given treatment, while the treatment in question is the application of learning models based on HOTS-based problems. Learning tools that will be developed are (1) Syllabus; (2) Learning Implementation Plan (RPP) using the problem-based learning model syntax; (3) Learning module; and (4) Assessment Sheet (LP) critical thinking skills and creative thinking abilities.

The data analysis technique is done by analyzing this ability using a high order thinking skills test. The problem used is a question that is adjusted to the indicators of high order thinking skills. The analysis is descriptive and inferential. Descriptive analysis was carried out for HOTS's ability, namely critical thinking ability and creative thinking ability based on what students obtained from the posttest value using calculations according to Mardapi below [7].

Ability $=\sum_{\text {waw }}$ (correct answer score) $/ \quad$ (overall score) $\quad \mathrm{x} \quad 100$ Inferential statistics are conducted to test the hypothesis proposed by analyzing the comparison of high order thinking skills between the experimental class and the control class. Tests were carried out with two-party t-test with the help of SPSS 23. The data used must meet the requirements that are normally distributed and homogeneous. The steps of testing the hypothesis are as follows: (1) The first prerequisite test to be carried out is the normality test, the test is carried out using the one sample kolmogorov-smirnov method with the help of 
SPSS 23 software with the level of sig. 0.05. While the second test is a homogeneity test, testing the similarity of variance between the two groups was carried out with the help of SPSS 23 software with the level of sig. 0.05. The homogeneity test of students in the experimental class and the control class through the Levene test. Furthermore, (2) test the hypothesis that is based on the preconditioning test above, then the hypothesis of this study is to analyze whether there are differences in the ability of students taught using problem-based learning tools and students taught using MPL learning devices, the hypothesis is formulated as follows.

Statistical hypothesis: H0: $\mu 1=\mu 2 \backslash$

H0: $\mu 1>\mu 2$

H0: $\mu 1=\mu 2$; the average ability for students who are taught using problem-based TDO learning devices is the same as the ability for students who are taught by using DI.

H1: $\mu 1>\mu 2$; the average ability for students who are taught by using problem-based TDO learning devices is higher than the ability for students who are taught by using DI.

Testing the ability to use the independent sample t-test. Tests were conducted to determine whether there were differences in the average experimental class with the control class. After getting the calculation data, then the next step is to determine or draw conclusions if obtained sig> 0.05 can be estimated non-significant, if obtained sig $\leq 0.05$ can be estimated significantly, and if obtained $\operatorname{sig} \leq 0.01$ can be estimated very significantly. The next stage, (3) the n-gain test, this test is conducted to determine the effectiveness of the learning model in improving abilities. This study conducted a n-gain test using SPSS version 23. The last stage, (4) Effect Size test, this test was carried out to clarify the amount of donation given in improving ability. contribution effect (effect size) is calculated using the cohen formula d, as follows [8].

Cohen size $\mathrm{d}=$ (average difference $) /($ standard deviation $)$ The effect size contribution criteria if $0.0-0.2=$ small effect, if $>0.2-0.8=$ medium effect, and if $>0.8-2.0=$ big effect.

\section{Result and Discussion}

Nieveen explained the effectiveness of a product occurs when the expected learning increases from the target group [9]. So, learning devices are said to be effective if the learning device can help students to achieve predetermined indicators.

\subsection{Critical Thinking Ability}

Based on the tests that have been conducted, data obtained on the level of critical thinking skills of students of SMK Negeri 1 Jetis Mojokerto as shown in Table 1, below.

\begin{tabular}{rlll}
\hline No. & Aspects of Critical Thinking & Experimental groups & control groups \\
\hline 1 & Interpretation & 80,71 & 70,67 \\
\hline 2 & Analysis & 81,61 & 72,17 \\
\hline 3 & Inference & 80,89 & 72,67 \\
\hline 4 & Evaluation & 88,93 & 73,17 \\
\hline 5 & Explanation & 83,75 & 70,83 \\
\hline 6 & Self regulation & 81,25 & 68,5 \\
\hline
\end{tabular}

Table 1. Level of Critical Thinking Ability of Students of SMK Negeri 1 Jetis Mojokerto 
If drawn in graphical form, the level of critical thinking skills of students of SMK Negeri 1 Jetis Mojokerto covers 6 aspects as shown in Figure 1 below.

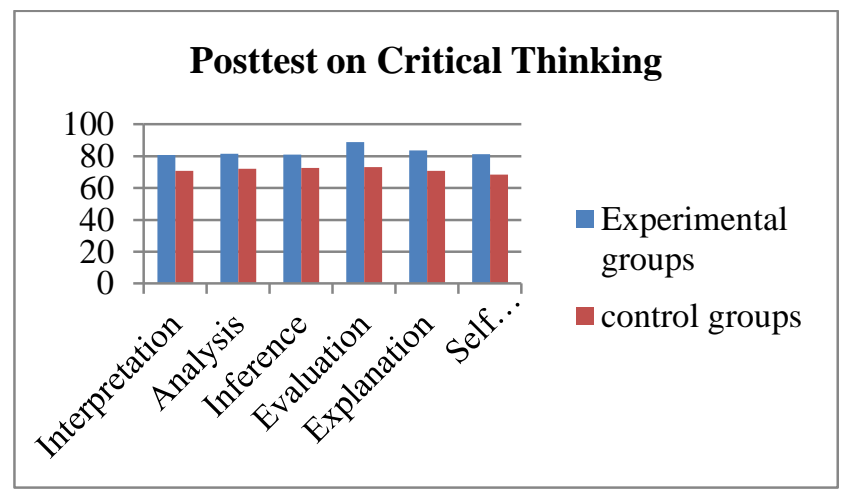

Figure 1. Level of critical thinking skills of students of SMK Negeri 1 Jetis Mojokerto

Based on the results of the requirements test that has been done, it can be concluded that the data level of critical thinking skills of students of SMK Negeri 1 Jetis Mojokerto is derived from populations that are normally distributed and homogeneous variances. Furthermore, the data on the level of critical thinking skills of students at SMK Negeri 1 Jetis Mojokerto was analyzed using the independent sample t-test as shown in Table 2 below.

\begin{tabular}{lllll}
\hline & & t & df & Sig. (2-tailed) \\
\hline \multirow{2}{*}{ Posttest on critical thinking } & Equal variances assumed & 8,33 & 56 & $\mathbf{0 0 0}$ \\
\cline { 2 - 5 } & Equal variances not assumed & 8,034 & 55,85 & $\mathbf{, 0 0 0}$ \\
\hline
\end{tabular}

Table 2 Test the independent sample t-test on the level of critical thinking skills Students of SMK Negeri 1 Jetis Mojokerto

Based on Table 2, it can be seen that the level of sig. 0,000 10.01 so it can be concluded that the average score of critical thinking skills for students who learn using HOTS-based problem-based learning (PBL) models $\left(\mathrm{x}^{-}=82.96\right)$ is significantly higher than students who learn using direct instruction model (DI) with an average score of $\mathrm{x}^{-}=71.40$. Furthermore, a size effect test was held to determine the amount of contribution of the problem-based learning model (PBL) based on HOTS on improving students' critical thinking skills. Based on the description of $\mathrm{N}$-gain test data, the mean value $\left(\mathrm{x}^{-}=49.30\right)$ is obtained in the experimental class with a standard deviation $(\sigma=6.64)$ while the control class has a mean value $\left(\mathrm{x}^{-}=39.33\right)$ with a standard deviation $(\sigma=7.99)$. The cohen $d$ effect size value is 1.3 so that it can be concluded that the HOTS-based problem-based learning model (PBL) contributes greatly to the level of students' critical thinking abilities.

According to Anindyta \& Suwarjo critical thinking ability is one of the abilities that must be possessed by students. This ability is very useful for students in facing the conditions that exist in today's society which are expected not to receive information just like that without sorting out which information is useful or not for him [10]. Based on Table 1 it appears that 
the level of critical thinking ability of the experimental class which has the highest score is the evaluation aspect which is equal to 88.93. The results of this study are in accordance with the results of Prasetyani, Hartono, \& Susanti's research which concluded that by using a problembased learning model, the ability to analyze and evaluate students had good criteria [11].

Evaluation is a representation of the ability to provide an explanation of the description of a person's perceptions, experiences, situations, considerations, beliefs or opinions, and as proof of the logical strength of actual or desired inferential relationships including statements, descriptions, questions or other forms of representation. This opinion is in line with Rusman's opinion that problem-based learning (PBL) becomes the starting point in learning, where the problems raised are problems that exist in the real world that are unstructured, so PBL can improve the ability to evaluate and review experiences for students [12]. While the lowest score according to the data in Table 1 is the interpretation aspect of 80.71 . This is because students who are still difficult to understand the meaning of an event. As explained by Nur, Nasution, \& Suryanti that interpretation is understanding and expressing the meaning or meaning of various experiences, situations, data, events, judgments, conventions, beliefs, rules, procedures, or broad criteria [13].

The results of this study are in line with the results of Nofal's research which carried out research on the synthesis of the development of high order thinking, with the title "the role of syntax in developing the higher-order thinking skills of EFL / ESL students", which concluded that HOTS could train students to think creatively and critical according to the purpose of learning, so HOTS can be developed and trained in learning [14]. Thus there is no need to hesitate anymore to develop critical thinking skills in students because this ability is very important as a provision for students to work and to face community life. Based on the results of several studies that critical thinking skills for students who learn using PBL-based learning are higher than students who learn using the DI learning device.

\subsection{The ability to think creatively}

Based on the tests that have been conducted, data obtained on the level of critical thinking skills of students of SMK Negeri 1 Jetis Mojokerto as shown in Table 3, below.

\begin{tabular}{clll}
\hline No. & Aspects of Cretive Thinking & Experimental groups & control groups \\
\hline 1 & Fluency & 82,5 & 75,83 \\
\hline 2 & Flexibility & 81,61 & 76,67 \\
\hline 3 & Originality & 76,79 & 70,83 \\
\hline 4 & Elaboration & 82,86 & 75,17 \\
\hline \multicolumn{2}{c}{ Table 3.Level of Critical Thinking Ability of Students of Vocational High School 1 Jetis Mojokerto } \\
If drawn in graphical form, the level of creative thinking ability of students of SMK Negeri \\
1 Jetis Mojokerto covers 4 aspects, as shown in Figure 1 below.
\end{tabular}




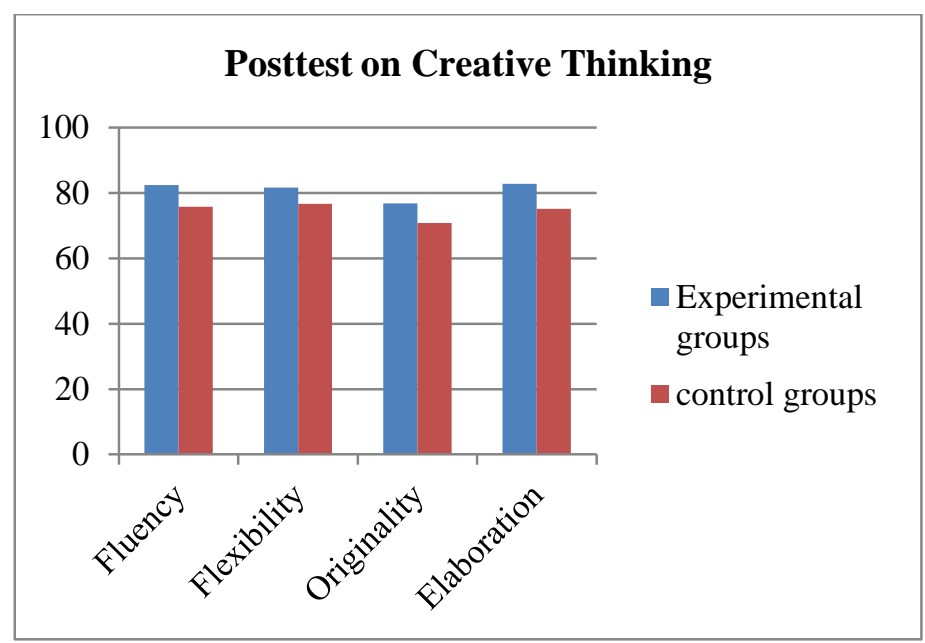

Figure 2. Stundent Achievement posttest on creative thinking

Based on the results of the requirements test that has been done, it can be concluded that the data on the level of creative thinking ability of students of SMK Negeri 1 Jetis Mojokerto are derived from populations that are normally distributed and homogeneous variances. Furthermore, the data level of critical thinking skills of students of SMK Negeri 1 Jetis Mojokerto was analyzed using the independent sample t-test as shown in Table 4 below.

\begin{tabular}{llcc}
\hline & t & df & $\begin{array}{c}\text { Sig. } \\
\text { (2-tailed) }\end{array}$ \\
\hline Posttest on creative thinking Equal variances assumed & 7,6056 & $\mathbf{, 0 0 0}$ \\
\cline { 2 - 4 } & Equal variances not assumed $7,6155,89$ & $\mathbf{, 0 0 0}$ \\
\hline
\end{tabular}

Table 4. Test the independent sample t-test on the level of creative thinking skills Students of SMK Negeri 1 Jetis Mojokerto

Based on Table 4, it can be seen that the level of sig. 0,000 10.01 so it can be concluded that the average score of creative thinking skills for students who learn using HOTS-based problem-based learning (PBL) models $\left(\mathrm{x}^{-}=49.14\right)$ is significantly higher than students who learn using direct instruction model (DI) with an average score of $\mathrm{x}^{-}=74.66$. Furthermore, a size effect test was held to determine the amount of contribution of the problem-based learning model (PBL) based on HOTS on improving students' creative thinking skills. Based on the description of $\mathrm{N}$-gain test data, the mean value $\left(\mathrm{x}^{-}=49.14\right)$ is obtained in the experimental class with a standard deviation $(\sigma=3.66)$ while the control class has a mean value $\left(\mathrm{x}^{-}=43.63\right)$ with a standard deviation $(\sigma=4.49)$. The cohen effect size value is 0.67 so it can be concluded that the HOTS-based problem-based learning model (PBL) contributes to the moderate category of students' creative thinking abilities.

According to Nurlaela \& Ismayati creative thinking ability is interpreted as a mental activity that is used by a person to build new ideas or ideas fluently and flexibly [6]. The ability to think creatively is an ability that has indicators such as fluency, flexibility, originality, and elaboration. Based on Table 3 the level of creative thinking ability of the 
experimental class shows that the aspects that have the highest score are aspects of elaboration which is equal to 82.86 . Whereas the aspect that has the lowest score is the originality aspect which is equal to 76.79 . This is due to the difficulty of students producing new ideas. This opinion was supported by the results of research by Heong, Yunos, Othman, Hassan, Kiong, \& Mohamad who found that the difficulties experienced by students were to produce an idea, and the difficulty was as a determining factor in achieving student assignments [15].

The results of this study are in line with the results of Ardiana \& Sudarmin's research on the application of self-assessment for the analysis of high order thinking students by using 4 aspects of HOTS namely decision making, problem-solving, critical thinking, and creative thinking [16]. The results of the study concluded that the level of achievement of the four aspects of high-level thinking skills had not shown satisfactory results, especially there were two aspects with poor performance levels, namely the critical thinking aspect of 68.5 and creative thinking aspects of 68 . Based on several research results, the ability to think creatively for students who learn using PBL-based learning is significantly higher than students who learn using the DI learning device.

High order thinking skills (HOTS) can be developed in each learning activity by integrating assessment in learning. According to Widihastuti, the assessment system must be integrated in learning and directed to the development of critical thinking skills, logical, systematic, analysis, synthesis, and creating / evaluative, as well as problem-solving, and the formation of positive attitudes and behaviors [16]. Problem-based learning (PBL) or commonly known problem-based instruction $(\mathrm{PBI})$ is one learning model that has the concept of contextual learning. Problem-based learning gives the understanding that student learning is given to a problem, which is then expected through problem-solving learners learn more fundamental thinking skills. In addition, Norman and Schmidt in the directorate of Vocational School writing the purpose of PBM is to improve the ability to apply concepts to new/real problems and to integrate the concept of high order thinking skills.

Research conducted by Budsankom, Sawangboon, Damrongpanit, \& Chuensirimongkol concluded that there were 4 contributions affecting HOTS namely psychological characteristics, class environment, family characteristics, and intellectual characteristics [17]. HOTS learning according to King, Godson, \& Rohani, requires clear communication so as not to confuse students and improve student attitudes in doing assignments [18]. Furthermore, King, Godson \& Rohani said that the learning plan must include applied thinking and gradual learning needed, to support students at the beginning of the lesson and gradually help students to learn independently [18]. Based on the results of several studies, one of them according to Widodo \& Kadarwati stated that HOTS would be better if it was associated with problemsolving instruction or problem-based instruction because the estuary of high-level thinking patterns was able to solve problems [19].

This opinion is reinforced by Handayani \& Priatmoko who stated that problem-solving learning can stimulate students' high-level thinking skills such as critical and creative thinking [20]. Likewise according to Ulfa in his research which concluded that students' high-level thinking skills taught with problem-based learning strategies were significantly higher than traditional learning [21].

In addition, the results of Prasetyani, Hartono, \& Susanti's research concluded that students in completing high order thinking skills after being taught using a problem-based learning model had criteria both in terms of the ability to analyze and evaluate aspects and lacking in aspects of the ability to create [11]. Problem-based learning models are based on the many problems that require authentic investigation [22]. As Arends argues that problem-based 
learning is learning that teaches students to work on authentic problems with the aim of compiling their own knowledge, as well as developing higher inquiry and thinking skills [23].

Based on the results of this study and some of the results of the studies described above, the strategy of developing HOTS conducted by teaching students through learning models based on HOTS-based problems, and developing HOTS-based assessments, is effective for use in learning.

More specifically, HOTS's advantage in the automotive industry is that there have been rapid changes in development and evolution. In the manufacture of automotive vehicles, there has been a shift from the use of analog systems to digital systems, from carburetors to fuel injection systems, even hybrid systems. These conditions indicate that the automotive world is experiencing technological developments that are so very fast. This has an impact and raises a big problem in the world of education, namely the occurrence of a huge gap between the world of education and the industrial world. Based on that fact, and to deal with a very rapid world change, education in the century of knowledge or the 21 st century must be able to develop habits of critical thinking and creative thinking. Problem-based learning model is a learning model that uses a variety of thinking abilities from students individually or in groups, as well as the real environment to overcome problems so that they become more meaningful, relevant, and contextual.

\section{Conclusion}

Based on the results of the research and discussion as described above, it can be concluded that: (1) the average score of critical thinking skills for students who learn using HOTS-based problem-based learning (PBL) models $\left(\mathrm{x}^{-}=82.96\right)$ is higher significantly compared to students who studied using direct instruction (DI) models with an average score of $\mathrm{x}^{-}=71.40$; and (2) the average score of creative thinking ability for students who learn using HOTSbased problem-based learning (PBL) models $\left(\mathrm{x}^{-}=49.14\right)$ is significantly higher than students who learn using direct or direct learning models instruction (DI) with an average score of $\mathrm{x}^{-}=$ 74.66 .

\section{Suggestion}

Based on the results of the research that has been obtained, it is conveyed suggestions to the parties related to this research that the development of learning devices with problem based learning models based on high order thinking skills (HOTS), needs to be adjusted to the level of understanding of students, so that the results can be maximized.

\section{References}

[1] Widihastuti and Suyata, "Model AFL untuk meningkatkan pemahaman dan higher order thinking skills mahasiswa vokasi bidang busana," J. Penelit. dan Eval. Pendidik., vol. 18, no. 2, pp. 275-289, 2014.

[2] K. Cotton, Developing employability skills School improvement research series Research you can use. Virginia, 1993.

[3] J. P. Robinson, "What are employability skills the workplace: A fact sheet." 2000.

[4] C. C. Chinedu, Y. Kamin, and O. S. Olabiyi, "Strategies for improving higher order thinking skills in teaching and learning of design and technology education," J. Tech. Educ. Train., vol. 7, no. 2, pp. 35-43, 2015. 
[5] M. Samani and Suparji, "Teaching-Learning Strategy For Developing Critical Thinking And Creativity For Engineering Student Teachers," in TVET International Conference at Bremen University-Germany, 2015.

[6] L. Nurlaela and E. Ismayati, Strategi Belajar Berpikir Kreatif. Yogyakarta: Ombak, 2015.

[7] D. Mardapi, Teknik Penyusunan Instrumen Tes dan Non Tes. Yogyakarta: Mitra Cendikia Offset, 2008.

[8] J. Cohen, Statistical Power Analysis For The Behavioral Sciences. Hillsdale, NJ: Lawrence Earlbaum Associates, 1988.

[9] N. Nieveen, Prototyping to Reach Product Quality. London: Kluwer Academic Publisher, 1999.

[10] P. Anindyta and Suwarjo, "Pengaruh problem based learning terhadap keterampilan berpikir kritis dan regulasi diri siswa kelas V," J. prima edukasia, vol. 2, no. 2, pp. 209-222, 2014.

[11] E. Prasetyani, Y. Hartono, and E. Susanti, "Kemampuan berpikir tingkat tinggi siswa kelas XI dalam pembelajaran trigonometri berbasis masalah di SMA Negeri 18 palembang," J. Gantang, vol. 1, no. 1, pp. 31-40, 2016.

[12] Rusman, Seri managemen sekolah bermutu, model-model pembelajaran mengembangkan profesionalisme guru. Depok: Rajagrafindo persada, 2012.

[13] M. N. Nur and J. Suryanti, Berpikir kritis. Surabaya: Unipress, 2013.

[14] K. Nofal, "The Role of Syntax in Developing the Higher Order Thinking Skills of EFL/ESL Students," Br. J. Educ. Soc. Behav. Sci., vol. 5, no. 2, pp. 181-198, Jan. 2015.

[15] Y. M. Heong, J. M. Yunos, W. Othman, R. Hassan, T. T. Kiong, and M. M. Mohamad, "The Needs Analysis of Learning Higher Order Thinking Skills for Generating Ideas," Procedia - Soc. Behav. Sci., vol. 59, pp. 197-203, Oct. 2012.

[16] Widihastuti, "Strategi pendidikan karakter di perguruan tinggi melalui penerapan assesment for learning berbasis higher order thinking skills," J. Pendidik. Karakter, vol. 3, no. 1, pp. 38-52, 2013.

[17] B. Prayoonsri, S. Tatsirin, D. Suntorapot, and C. Jariya, "Factors affecting higher order thinking skills of students: A meta-analytic structural equation modeling study," Educ. Res. Rev., vol. 10, no. 19, pp. 2639-2652, Oct. 2015.

[18] F. J. King, L. Goodson, and F. Rohani, "Higher order thinking skills Definitions Teaching Strategies Assessment," in A publication of the educational services program, now known as the center for advancement of learning and assessment, 2010.

[19] T. W. Dan Sri Kadarwati, "Higher order thinking berbasis pemecahan masalah untuk meningkatkan hasil belajar berorientasi pembentukan karakter siswa," J. Cakrawala Pendidik., vol. 5, no. 1, pp. 161-171, May 2013.

[20] R. Handayani and Priatmoko, "Pengaruh pembelajaran problem solving berorientasi HOTS (higher order thinking skills) terhadap hasil belajar kimia kelas X," J. Inov. Pendidik. Kim., vol. 7, no. 1, pp. 1051-1062, 2013.

[21] W. Ulfa, "Pengaruh strategi pembelajaran berbasis masalah terhadap kemampuan berpikir tingkat tinggi (menganalisis, mengevaluasi, mencipta) dan keterampilan proses sains mahasiswa STIPAP LPP medan,” J. UNIMED, vol. 1, no. 5, 2013.

[22] Trianto, Model-model pembelajaran inovatif berorientasi konstruktivis. Jakarta: Prestasi pustaka, 2011.

[23] R. I. Arends, Classroom instructional and management. New York: The McGrw-Hill Companies, 1997. 
